3-1992

\title{
Teaching American Government in a Comparative Context
}

Barbara B. Green

Cleveland State University, b.green@csuohio.edu

Follow this and additional works at: https://engagedscholarship.csuohio.edu/clpolsci_facpub

How does access to this work benefit you? Let us know!

Publisher's Statement

Copyright 1992 Cambridge University Press. Available on publisher's site at

http://www.jstor.org/stable/419577.

\section{Original Citation}

Green, Barbara B. 1992. "Teaching American Government in a Comparative Context." PS: Political Science and Politics 25:81-82.

\section{Repository Citation}

Green, Barbara B., "Teaching American Government in a Comparative Context" (1992). Political Science Faculty Publications. 5.

https://engagedscholarship.csuohio.edu/clpolsci_facpub/5

This Article is brought to you for free and open access by the Political Science Department at EngagedScholarship@CSU. It has been accepted for inclusion in Political Science Faculty Publications by an authorized administrator of EngagedScholarship@CSU. For more information, please contact library.es@csuohio.edu. 


\title{
Teaching American Government in a Comparative Context
}

\author{
Barbara B. Green, Cleveland State University
}

D uring nearly a decade as a university administrator I taught an advanced course in Soviet politics. When I returned to full-time teaching last fall, the chair asked me to teach a course in introductory American government. I looked at this as a challenge and an opportunity.

Although most of our American government classes at Cleveland State University have 120 students and use multiple choice examinations, we agreed to limit my class to $60 \mathrm{stu}-$ dents and to require essays.

One of the advantages of teaching American government is that the students know a great deal about the system in which they live. Being part of the system, however, makes it harder for them to assess its strengths and weaknesses. Sometimes students find it difficult to determine what really counts in the political system, what is important or not important. Teaching American government in a comparative framework can lead them to a more critical approach.

A useful comparison is provided by the republics of the former Soviet Union during the current period of profound change. The future political and economic arrangements among them are uncertain. Although Yeltsin and his supporters may be committed to democracy, they do not know how democracy operates in practice. Soviet scholars, intellectuals, and government figures are looking at the experience of the United States to see how constitutional democracy operates and to determine what aspects of the American system can be borrowed and integrated into their context. The Federalist Papers have become almost required reading for them. Those planning the future of the Commonwealth of Independent States are seeking information about the way the American system operates, why it has lasted, how it has dealt with challenges, and how it preserves demo- cratic values. This gives Americans an opportunity to view our own system from a new perspective.

Students in my American Government class are asked to play the role of experts on American politics being consulted by representatives from the former Soviet republics and central government who are anxious to learn about the American political system. The students are reminded that they are not expected to be genuine experts on Soviet politics, but that some general knowledge of the basic problems facing the Commonwealth is useful.

Background information at a basic level can be found in Global Studies, The Soviet Union and Eastern Europe (Dushkin, 1990), although this and every other text has been severely dated by the events of last August. Nevertheless, it provides important contextual information. Students are expected to read the material found in The New York Times News of the Week in Review of September 1, 1991, which includes a brief summary of the histories, peoples, and strengths of the republics. Although I am reluctant to encourage students to rely on popular news magazines, the September 9, 1991, issue of Time has useful information presented at a level easily comprehended by beginning students. Students are expected to read a daily newspaper, preferably The New York Times or Washington Post, but current developments of particular significance are discussed in class, and student attention is drawn to articles relating important developments.

The syllabus points out key factors that students need to take into account, and these are reinforced by the instructor in class. Students are told that the outlook of political leaders and followers is conditioned by the cumulative historical experiences of their respective countries. The historical experience affects the belief systems that legitimize the system. When they result in an under- lying consensus, the task of governing is far less complicated than when there are permanent rifts and divisions. Furthermore, every political system shapes and is shaped by the society of which it is a part.

Students are cautioned to avoid assuming that just because some aspect of our system works for us, it would necessarily work when transferred to another system. They should be aware that parts of our system are dependent on other parts, on our unique history, and on our political values. If some aspect of our political system works well, students are told, we need to ask why it is effective. Could it be effective in another society? If some aspect of our system seems to work less well, again we need to ask why. We cannot simply transfer institutions from one system to another and expect them to take root and work.

In class, we review key concepts, ideas, and facts under each of the traditional topics of American government, but concentrate on discussing similarities to and differences from the former Soviet Union. The intent is not to teach Soviet politics but rather to use the comparisons to shed light on the American political system. When, for example, the textbook refers to America as a country of individuals from different religions, races, ethnic groups, and cultural traditions, discussion focuses on comparisons with the multicultural Soviet Union.

Issues of assimilation, separatism, ethnicity, and discrimination can be examined from a different perspective than the one ordinarily used. Some students of East European backgrounds vehemently support the right of minority nationalities to educate their children in their own language and traditions and to take pride in their heritage. They then seem to look at current demands of black and Hispanic groups in America from a new angle. Some 
African-American students, looking at the dangers of ethnic warfare in the former Soviet Union, become concerned about the danger of reinforcing cleavages that might prevent the creation of shared values and even the minimal consensus necessary for survival of a political system. They question the desirability of too much emphasis on separatism in the United States.

One of the key issues facing the peoples of the former Soviet Union is refining the Union Treaty. Last year, my students were required to write two short papers of 3-5 pages. For the first paper, they were asked to compare and contrast the confederal aspects of the Articles of Confederation with the federal aspects of the United States Constitution. They were asked to consider why the states initially adopted a confederal system, how successfully the system met the needs of the states, and what led the framers of the Constitution to the conclusion that a federal system was needed. The students were asked to consider the following: the issues of national and international trade, the need for a stable currency, the difficulties Congress had in raising money, and the problem of the reliability of international treaties when states could make or break them independently.

In class, it was noted that the founding fathers were, in Beard's words, "rich, well-born, and able," sharing a common culture and the ideals of The Enlightenment. Students were asked to consider how important this advantage was. Is it likely that states or republics with a heterogenous population and lacking common values would agree to cede major powers to a distant central government? Students were reminded that it took the Civil War to forge this fragile federal union, essentially "a collection of state baronies" into nationhood (see Bertram WyattBrown, "The South Against Itself," The New York Review of Books, October 10, 1991). It was not assumed that the students would tell the Soviets what to do but rather that they would relate the experiences of Americans with problems similar to those facing the Soviets today. Although the problems are similar, not only the similarities, but the differences in the setting of the problems were considered.

For the second paper, the following was posed: How important is money in politics in the United States? In the past, Soviet leaders and ideologues charged that in America those with money control elections, buy access to decisionmakers, and even buy decisions. How much truth, if any, is there in these charges? The republics hope to move toward a more democratic system and toward a market economy that will result in substantial differences in wealth and income. What, if anything, can be done to limit the influence of money in politics? Here, again, students need to be able to explain clearly how the American political system operates, including the role of PACs. They should be able to discuss efforts to control the role of money in politics and the difficulties encountered in this effort. Again, clearly, there is no assumption that the students will have knowledge of future political developments in the newly formed Commonwealth. They are simply asked to assume that Soviet representatives have asked them about problems in the United States so that the Soviets will be aware of our experience when they consider possible regulatory measures.

Students can, profitably, be asked to take a similar approach to other important issues. They could consider the importance of freedom of the press to a responsible democratic system and then consider in what circumstances, if any, a democratic government is justified in limiting this freedom. The temporary shutting down of Pravda by Boris Yeltsin after the abortive coup could be considered along with the Alien and Sedition Acts, wartime limitations, and restrictions imposed on the press in the cases of Granada, Panama, and the Gulf War. The class might consider the question of ensuring the rights of minorities against the majority which is important in the United States and is crucial to survival in the former Soviet republics and Yugoslavia. As one of my students this term noted, without ensured constitutional protections, minorities are dependent on the good will of the majority. Although students need some background on the problems of ethnic minorities in the Soviet Union, sufficient information is readily obtainable in the sources listed earlier.

The performance of students varied widely last year, as is always the case in an introductory course at Cleveland State, an open admission, urban, public university. Some students had never written an essay before, while others had relatively sophisticated writing skills. Some were recent graduates of inner-city high schools; some were upperclassmen in accounting taking the course to fulfill general distribution requirements; some were college graduates taking the course for teacher certification; and some were men and women in their forties returning to school to finish their degrees. There is a great variety of ethnic backgrounds, including many students whose native language is not English and whose earlier experiences were not with American government and politics.

I allow students to rewrite papers that are not satisfactory and urge them to take the papers to tutors, mentors, and our writing laboratory for help. Last year, many students worked very hard. They wrote and rewrote. The most important outcome was that the students thought about political questions instead of memorizing facts to pass multiple choice examinations. Class discussion was lively and even heated at times. Students were eager to mobilize facts in order to develop or challenge arguments. I am teaching the class again this year, altering it to keep up with changing developments and raising questions for consideration as they move to center stage.

\footnotetext{
About the Author

Barbara B. Green, professor of political science and formerly vice provost and acting provost at Cleveland State University, has published numerous articles in professional journals. Her interests are Russia and problems of contemporary democracy.
} 